Ekspansi: Jurnal Ekonomi, Keuangan, Perbankan dan Akuntansi

ISSN (Online): 2580-7668 ISSN (Print): 2085-5230

Vol. 12, No. 1 (Mei 2020), Hal. 31 - 42

\title{
PEMODELAN MULTIPLE DISCRIMINANTANALYSIS UNTUK MEMPREDIKSI FINANCIAL DISTRESS BANK UMUM SYARIAH DI INDONESIA
}

\author{
Radia Purbayati ${ }^{1}$, Kurnia Fajar Afgani ${ }^{2}$ \\ ${ }^{1}$ Jurusan Akuntansi, Politeknik Negeri Bandung, Bandung, Indonesia \\ ${ }^{2}$ School of Bussiness and Management, Institut Teknologi Bandung, Bandung, Indonesia \\ Email Korespondensi: radia@polban.ac.id
}

\begin{abstract}
The aims of this study is to set the financial distress prediction model and to identify the best accuraction and classification from the financial distress prediction model. The objects were 9 Islamic Banks in Indonesia since 2012 to 2017 using Multiple Discriminant Analysis modelling. The variables used financial ratios, consist of ROA, BOPO, Current Assets to Current Liabilities Ratio, NPF, Equity to Total Liabilities, and FDR. The outcome shows that a variable tend to cause an Islamic bank fall into financial distress condition dominantly was NPF ratio. The accuration prediction power with 42 from 42 obervations predicted fall into health bank category were classified correctly (100\%), and 2 from 12 Islamic Banks fall into financial distress category were classified incorrectly (16.7\%) and were corrected into helath bank category. The classification power created by multiple discriminant analysis was $81.48 \%$.
\end{abstract}

Keywords: Financial Distress, financial ratio, Multiple Discriminant Analysis.

Abstrak: Tujuan penelitian ini adalah melakukan pemodelan predikisi financial distress dan mengidentifikasi keakuratan prediksi serta daya klasifikasi dari model prediksi financial distress pada Bank Umum Syariah di Indonesia. Objek penelitian menggunakan 9 Bank Umum Syariah di Indonesia periode 2012 hingga 2017 menggunakan pemodelan Multiple Discriminant Analysis. Penelitian menggunakan rasio keuangan berupa ROA, BOPO, CA/CL, NPF, Equity/Total Liabilities dan FDR. Hasil menunjukkan bahwa hanya variabel NPF yang dominan cenderung menyebabkan suatu Bank Umum Syariah berada dalam kondisi Financial Distress. Analisis MDA mampu menghasilkan ketepatan prediksi suatu Bank Umum Syariah termasuk kedalam Bank Umum Syariah yang sehat sebanyak 42 observasi (100\%) dan tidak ada yang berpindah ke Kelompok yang mengalami financial distress. Sementara itu 2 observasi berada di kondisi financial distress dari dugaan awal sebanyak 12 Bank Umum Syariah dan terdapat 2 observasi (16.7\%) terkoreksi menjadi kelompok Bank Umum Syariah yang sehat. Ketepatan fungsi diskriminan adalah $81.48 \%$.

Kata Kunci: Financial Distress, Rasio Keuangan, Multiple Discriminant Analysis. 


\section{PENDAHULUAN}

Perbankan syariah dengan konsep Profit and Loss Sharing tumbuh dengan pesat di dunia sebagai alternatif perbankan konvensional yang menawarkan sistem bunga (JeanYves Moisseron, et al (2015), Mabid Ali Al-Jarhi (2017), Jana Ilieva (2017)). Pada praktiknya, perbankan syariah dihadapkan pada berbagai macam risiko perbankan. Berbagai langkah mitigasi risiko salah satunya melalui penerapan prinsip kehati-hatian dilakukan oleh perbankan guna mencegah suatu bank berada dalam kondisi financial distress. Financial distress merupakan tahapan penurunan kondisi keuangan suatu perusahaan sebelum terjadinya kebangkrutan ataupun likuidasi. Kebangkrutan juga sering disebut likuidasi perusahaan atau penutupan perusahaan atau insolvensi. Kebangkrutan sebagai kegagalan diartikan sebagai kegagalan keuangan (financial failure) dan kegagalan ekonomi (economic failure) (Ramadhani dan Lukviarman, 2009). Langkah mitigasi risiko dilakukan dengan memperhatikan The Basel Core Principle sebagai acuan dasar secara internasional dalam melaksanakan prinsip kehati-hatian praktek perbankan diantaranya ketentuan mengenai modal minimum, kebijakan, praktek dan prosedur baik dalam hal penyaluran dana serta evaluasi kualitas aktiva.

Pemodelan untuk memprediksi financial distress pada perbankan telah dilakukan pada berbagai negara. Jaffari (2017) membagi jenis-jenis model kebangkrutan bank menjadi tiga kategori yaitu statistical methods, artificial intelligence expert methods dan theoretical models.

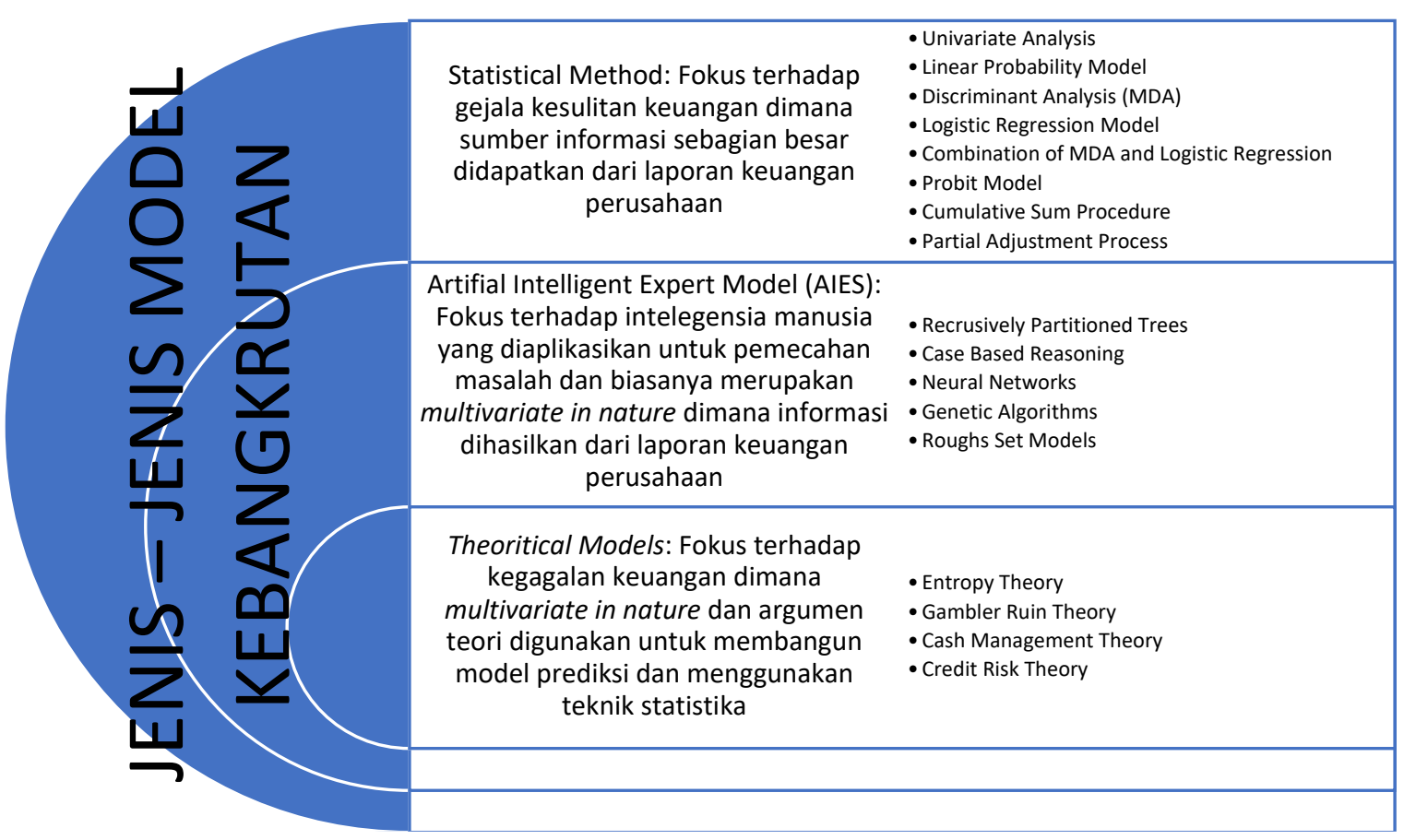

Gambar 1. Jenis-Jenis Model yang Digunakan Prediksi Kebangkrutan Perusahaan

Penelitian pemodelan prediksi kebangkrutan lebih didominasi dengan model Multiple Discriminant Analysis (MDA). Esensi dari pemodelan MDA adalah menentukan suatu model prediksi financial distress yang memiliki daya prediksi tinggi 
dan daya klasifikasi yang akurat yang dihasilkan dari pengkategorisasian cut off kondisi financial distress. Tzong-Huei Lin (2009) menguji kemampuan prediksi dan membangun model prediksi kegagalan untuk perusahaan publik di Taiwan. Ben Chin, etc (2010) mengembangkan model untuk memperbaiki kemampuan prediksi kondisi kesulitan perusahaan dalam konteks kondisi financial, bussiness dan operating yang berbeda pada perusahaan di Malaysia. Bunyaminu, Alhasan dan Mohammed Issah (2012) membandingkan dua model prediksi kesulitan keuangan perusahaan yaitu mengidentifikasi apakah rasio keuangan dapat digunakan sebagai indikator kesulitan keuangan pada perusahaan-perusahaan di UK. Mihalovič (2016) mengembangkan model prediksi kebangkrutan pada Republik Slovakia. Jaffari dan Zeesan (2017) memprediksi kebangkrutan perusahaan di Pakistan dengan menggunakan metode statistik dan juga mengidentifikasi keakuratan prediksi dan kemampuan prediksi dari metode tersebut.

Sebagian besar penelitian menekankan penyusunan model prediksi financial distress yang dilakukan terhadap perusahaan publik. Penelitian ini bertujuan untuk melakukan pemodelan predikisi financial distress pada Bank Umum Syariah di Indonesia dengan menggunakan Model Multiple Discriminant Analysis dan mengukur keakuratan prediksi dan daya klasifikasi dari financial distress pada Bank Umum Syariah di Indonesia.

\section{TINJAUAN PUSTAKA}

Terdapat beberapa definisi financial distress, sesuai tipenya, yaitu economic failure, business failure, technical insolvency, insolvency in bankruptcy, dan legal bankrupcty (Brigham dan Gapenski, 1997).

\section{Economic failure}

Economic failure atau kegagalan ekonomi adalah keadaan dimana pendapatan perusahaan tidak dapat menutupi total biaya termasuk cost of capitalnya yang berarti tingkat laba yang dihasilkan jauh lebih rendah dari biaya modal atau dengan kata lain tingkat arus kas sekarang lebih rendah dari kewajibannya.

\section{Business failure}

Kegagalan bisnis didefinisikan sebagai bisnis yang menghentikan kegiatan operasi dengan tujuan mengurangi kerugian kepada kreditur.

\section{Technical insolvency}

Sebuah perusahaan dikatakan dalam keadaan technical insolvency jika tidak dapat memenuhi kewajiban lancar ketika jatuh tempo. Ketidakmampuan membayar hutang secara teknis menunjukan kekurangan likuiditas yang sifatnya sementara, yang jika diberi waktu, perusahaan mungkin dapat membayar hutangnya dan survive. Pada kondisi ini, aset perusahaan masih bernilai lebih tinggi daripada utangnya.

\section{Insolvency in bankrupcty}

Sebuah perusahaan dikatakan dalam keadaan insolvent in bankrupcty jika nilai buku hutang melebihi nilai pasar aset. Kondisi ini lebih serius dari pada technical insolvency karena pada umumnya merupakan tanda dari economic failure, dan bahkan mengarah kepada likuidasi bisnis. 


\section{Legal bankrupcty}

Perusahaan dikatakan bangkrut secara hukum jika telah diajukan tuntutan secara resmi dengan undang - undang.

\section{METODE PENELITIAN}

Metode penelitian yang digunakan adalah penelitian deskriptif dengan pendekatan kuantitatif dengan menggunakan analisis MDA. Variabel yang digunakan pada penelitian adalah :

a. Variabel dependen menggunakan proksi kondisi financial distress suatu perusahaan yang merupakan variabel kategori, bernilai 0 jika Bank Umum Syariah berada dalam kondisi sehat dan bernilai 1 jika Bank Umum Syariah mengalami kondisi financial distress.

b. Variabel independen, menggunakan rasio yang meliputi aspek Profitabilitas, Likuiditas, utilisasi aset dan size bank umum syariah. Variabeltersebut diantaranya sebagai berikut :

Tabel 1. Variabel Independen dalam Penelitian

\begin{tabular}{|c|l|}
\hline Proksi & \multicolumn{1}{|c|}{ Rasio Keuangan } \\
\hline $\mathbf{X 1}$ & Return on Total Asstes (RoA) (\%) \\
\hline $\mathbf{X} 2$ & BOPO (\%) \\
\hline $\mathbf{X 3}$ & Current Asset / Total Asset (\%) \\
\hline $\mathbf{X} 4$ & NPF (\%) \\
\hline $\mathbf{X 5}$ & Equity / Total Liabilities (\%) \\
\hline X6 & FDR \\
\hline
\end{tabular}

Objek penelitian meliputi Bank Umum Syariah di Indonesia selama tahun 2012 hingga 2017 yaitu sebaanyak 13 Bank. Teknik penarikan sampel yang digunakan adalah teknik purposive sampling. Kriteria penarikan sample adalah Bank Umum Syariah yang mempublikasikan laporan keuangannya pada periode penelitian. Bank yang masuk dalam kriteria penarikan sampel penelitian berjumlah 9 Bank diantaranya Bank Muammalat Indonesia, Bank Syariah Mandiri, Bank Mega Syariah, BRI Syariah, Bank Syariah Bukopin, Bank Panin Syariah, Bank BJB Syariah, BCA Syariah, dan BNI Syariah.

\section{Multiple Discriminant Analysis (MDA)}

MDA digunakan untuk memprediksi keanggotaan grup dari sekumpulan prediktor. Analisis diskriminan menekankan pada penemuan kombinasi linier terhadap dua atau lebih prediktor yang mampu melakukan diskriminasi diantara kelompok-kelompok gagal atau perusahaan yang tidak gagal. Hal ini dapat dicapai dengan memaksimalkan varians antar kelompok relatif ke varians dalam grup. Hubungan ini diberikan oleh fungsi kriteria Fisher dengan persamaan sebagai berikut :

$$
J(w)=\frac{w^{T}\left(\sum_{i}\left(x_{i}-\mu\right)^{T}\left(x_{i}-\mu\right)\right) w}{w^{T}\left(\sum_{c} \sum_{i \epsilon c}\left(x_{i}-\mu_{c}\right)^{T}\left(x_{i}-\mu_{c}\right)\right) w},
$$

dimana $w$ menunjukkan matriks proyeksi yang memaksimalkan rasio faktor penentu antara varians grup dengan determinan varians grup, $x$ menyajikan nilai-nilai 
dari sample, $\mu$ adalah mean dari sample, $w^{T}$ mengacu pada matriks proyeksi yang dialihkan, penjumlahan atas $c$ berarti menjumlahkan dalam kelas, $\mu$ adalah rata-rata kelompok untuk kelas $c$. Metode diskriminan mengestimasi fungsi diskrimainan dengan vektor $\mathrm{A}\left(a_{1}, a_{2}, a_{3}, \ldots, a_{n}\right)$ dengan kombinasi linier sebagai berikut :

$$
Z_{i}=a_{0}+a_{1} x_{i 1}+a_{2} x_{i 2}+a_{3} x_{i 3}+\cdots+a_{n} x_{i n}
$$

dimana $Z_{i}$ adalah skor diskriminaan perusahaan ke-i dan $x_{1}, x_{2}, \ldots, x_{n}$ adalah $n$ variabel-variabel $n$ untuk $i$ perusahaan. Setelah asumsi mendasar diverifikasi, MDA menghitung koefisien diskriminan dan skor diskriminan untuk masing-masing perusahaan yang dimasukkan. Tambahan prosedur pilih skor cut off yang sesuai yang akan menjaga esensi kriteria Fisher berfungsi dan memaksimalkan rasio varians antaragrup dengan varians dalam-grup. Dengan menggunakan slor $\mathrm{Z}$ dan mennetukan cut off, sebuah perusahaan dikategorikan gagal atau tidak gagal.

Proksi variabel dependen pada penelitian ini mengacu pada PBI No. 13/3/PBI/2011 Tentang Penetapan Status Bank dan Tindak Lanjut Pengawasan. Pada peraturan tersebut dikatakan bahwa Bank Indonesia berwenang menetapkan pengawasan Bank (Bank Umum sebagaimana dimaksud dalam Undang-Undang Nomor 7 Tahun 1992 tentang Perbankan sebagaiman telah diubah dalam UndangUndang Nomor 10 Tahun 1998 dan Bank Umum Syariah sebagaimana dimaksud dalam Undang-Undang No 21 Tahun 2008 tentang Perbankan Syariah). Status pengawasan Bank terdiri dari pengawasan normal, pengawasan intensif dan pengawasan khusus. Bank Indonesia menetapkan Bank dalam pengawasan intensif apabila dinilai memiliki potensi kesulitan yang membahayakan kelangsungan usahanya apabila memenuhi satu atau lebih kriteria berikut :

a. rasio Kewajiban Pemenuhan Modal Minimum (KPMM) lebih dari 8\% namun kurang dari rasio KPMM yang mempertimbangkan potensi kerugian sesuai profil risiko Bank yang ditetapkan oleh Bank Indonesia.

b. Rasio modal inti (tier 1) kurang dari persentase tertentu yang ditetapkan oleh Bank Indonesia.

c. Rasio Giro Wajib Minimum (GWM) dalam Rupiah sama dengan atau lebih besar dari rasio yang ditetapkan untuk GWM Bank, namun memiliki permasalahan likuiditas mendasar.

d. Rasio kredit atau pembiayaan bermasalah (NPF) secara netto lebih dari 5\%dari total pembiayaan.

e. Peringkat risiko Bank tinggi (high risk) berdasarkan hasil penilaian terhadap keseluruhan risiko (composite risk).

f. Peringkat komposit tingkat kesehatan Bank 4 atau 5.

g. Peringkat komposit tingkat kesehatan Bank 3 dengan peringkat faktor manajemen 4 atau 5.

Bank Indonesia menetapkan Bank dalam pengawasan khusus apabila dinilai memiliki potensi kesulitan yang membahayakan kelangsungan usahanya apabila memenuhi satu atau lebih kriteria berikut:

a. Rasio KPMM kurang dari 8\%. 
b. Rasio GWM dalam rupiah kurang dari rasio yang ditetapkan untuk GWM Bank dan berdasarkan penilaian Bank Indonesia :

- Bank mengalami permasalahan likuiditas mendasar.

- Bank mengalami perkembangan yang memburuk dalam waktu singkat.

- Jangka waktu Bank dalam pengawasan intensif terlampaui

Berikut adalah variabel dependen dan independen yang digunakan dalam analisis MDA.

Tabel 2. Variabel Penelitian

\begin{tabular}{|c|c|c|c|}
\hline No. & Variabel & Definisi Operasional & Simbol \\
\hline 1 & Financial Distress & 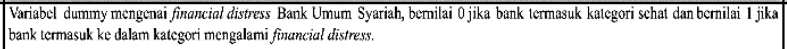 & $\mathrm{Y}$ \\
\hline 2 & ROA & Mengukur seberapa efektif aset-sset pada bank umum syariah digunakan untuk menghasilkan laba. & $x_{1}$ \\
\hline 3 & BOPO & 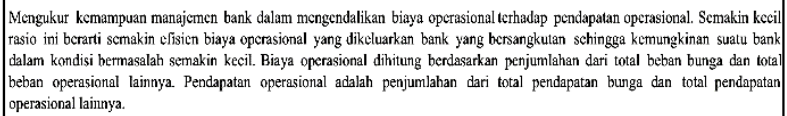 & $x_{2}$ \\
\hline 4 & CNCL & Menujjukkan seberapa besar kemampuan aset kancar daoat digguakan untuk menutupi kewajiban jangka pendeknya. & $x_{3}$ \\
\hline 5 & NPF & $\begin{array}{l}\text { Mengukur tingkat permasalahan pembiayaan yang dihadapi oleh bank. Semakin rendah rasio, semakin baik pembiayaan yang } \\
\text { dilakukan oleh bank. }\end{array}$ & $X_{f}$ \\
\hline 6 & ETL & 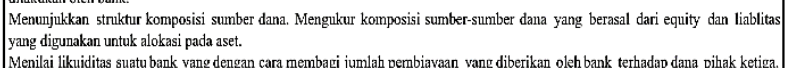 & $x_{s}$ \\
\hline 7 & FDR & $\begin{array}{l}\text { Semakin tinggi rasio ini, scmakin rendahnya kemampuan likuiditas bank yang bersangkutan schingga kemungkinan suatu bank } \\
\text { dalam kondisi bermasalah akan scmakin besar. }\end{array}$ & $x_{6}$ \\
\hline
\end{tabular}

\section{HASIL DAN PEMBAHASAN}

Analisis MDA dilakukan dengan metode stepwise (metode bertahap). Penentuan variabel-variabel yang paling efisien di dalam membedakan antar Bank Umum Syariah yang dikategorikan sehat dan mengalami financial distress. Mahalanobis distance (jarak Mahalanobis) akan digunakan untuk prosedur stepwise guna menentukan variabel yang memiliki kekuatan terbesar mendiskriminasi. Prosedur stepwise dimulai memasukkan variabel yang akan memaksimumkan Mahalanobis distance antar group. Dalam hal ini minimum nilai signifikansi 0,05 digunakan sebagai syarat enter variabel dan Mahalanobis D2 digunakan untuk memilih variabel.

Hasil pengolahan data menunjukkan hanya terdapat satu variabel rasio keuangan yakni X4 (NPF) yang mempunyai nilai wilk's lambda dengan nilai signifikansi dibawah 0.05 seperti terlihat pada Tabel 3. Dengan melihat tingkat signifikansi maka dapat disimpulkan bahwa variabel independen X4 (NPF) signifikan sehingga mampu membedakan antara kelompok Bank Umum Syariah yang dikategorikan sehat dan mengalami financial distress.

Tabel 3. Hasil Estimasi Fungsi Diskriminan

\begin{tabular}{|l|c|c|c|c|c|c|}
\hline Variabel & Koefisien & Eigen Value & Wilks' Lambda & Chi Square & df & Sign. \\
\hline X4 & 00.34 & 0,57083333 & 0,38125 & 30.91 & 1 & 0 \\
\hline Constant & -1.438 & & & & & \\
\hline
\end{tabular}

Sumber: SPSS, diolah kembali.

Tabel diatas menyajikan variabel mana yang dapat dimasukkan (entered) dalam persamaan diskriminan dimulai dari variabel yang memiliki angka F statistik terbesar. Hanya terdapat satu variabel saja yang terpilih yaitu NPF. Variabel ini memiliki angka signifikan lebih kecil dari 0.05. Dengan demikian, dari enam variabel yang dimasukkan untuk rasio keuangan dalam memprediksi kondisi financial distress Bank Umum 
Syariah, hanya terdapat satu variabel yang signifikan. Sehingga, variabel NPF secara signifikan mempengaruhi kondisi financial distress suatu Bank Umum Syariah. Varians total yang tidak dapat dijelaskan oleh skor diskriminan pada saat variabel NPF dimasukan ke dalam model adalah 0,549 atau 54,9\%. Hasil uji Eigenvalue pada koefisien korelasi Canonical menunjukan keeratan hubungan antara skor diskriminan yang dihasilkan dengan kelompok Bank Umum Syariah yang sehat dan yang mengalami financial distress berdasarkan nilai rata-rata periode 2012-2017 berada pada kategori kuat $(\mathrm{CC}=0,672)$. Kemampuan variabel diskriminan NPF untuk menjelaskan variasi antar kelompok Bank Umum Syariah yang sehat dan yang mengalami financial distress pada penelitian ini adalah $0,672^{2} \times 100 \%=45.1584 \%$.

Tabel di atas juga menunjukkan bahwa besaran nilai Wilks'Lambda adalah 0,549 dengan Chi-square 30.910 dan nilai signifikansi adalah 0,000 yang berarti fungsi diskriminan yang dihasilkan signifikan secara statistik, berarti nilai skor diskriminan untuk untuk kedua kelompok bank umum syariah berbeda secara statistik.

Fungsi diskriminan yang dihasilkan adalah sebagai berikut :

\section{$\mathrm{Z}$ Score $=-1.438+0.340 \mathrm{X} 4$}

Dari persamaan fungsi diskriminan tersebut, nilai koefisien konstanta model sebesar -1.438 memberikan arti bahwa pada saat nilai rasio NPF bernilai nol, maka Zscore yang dihasilkan adalah $-1,438$. Koefisien variabel rasio NPF sebesar 0.340 yang berbanding lurus dengan Z-score memberikan arti bahwa setiap terjadi perubahan rasio NPF sebesar $1 \%$, maka akan terjadi peningkatan nilai Z-score sebesar 0.340 kali. Persamaan model diskriminan ini digunakan untuk menghasilkan diskriminan score yang berfungsi untuk memprediksi pengklasifikasian suatu objek (kelompok mengalami financial distress atau kelompok sehat).

Dari hasil tabel Function of Group Centroids, dapat ditentukan critical cutting score untuk pengklasifikasian tiap perusahaan dengan fornula sebagai berikut

$\mathrm{ZCU}=\underline{(42 *(-0.476))+\left(12^{*} 1.665\right)}$

$42+12$

$\mathrm{ZCU}=-0.000222222$

Tabel 4. Functions at Group Centroids

\begin{tabular}{|c|c|}
\hline \multirow{2}{*}{$\mathrm{Y}$} & Function \\
\cline { 2 - 2 } & 1 \\
\hline Sehat & $\mathbf{- 0 . 4 7 6}$ \\
Financial Distress & $\mathbf{1 . 6 6 5}$ \\
\hline
\end{tabular}

Sumber: SPSS, diolah kembali.

Sehingga untuk penentuan nilai batas didasarkan pada nilai rata-rata dari jumlah $\mathrm{Z}$ total score dari masing-masing perusahaan yang diperoleh nilai $-0,000222$. Standar yang digunakan untuk menilai bahwa Bank Umum Syariah tersebut dikategorikan sehat atau mengalami financial distress adalah :

a. Bila Z score hitung <-0,000222 maka Bank Umum Syariah dikategorikan sehat. 
b. Bila Z score hitung > 0,000222 maka Bank Umum Syariah dikategorikan mengalami financial distress.

Ketepatan prediksi pengklasifikasian sampel terpilih awal (original group) dari fungsi diskriminan sebesar 100\%, misclassification pada kategori error type I sebesar $0 \%$ dan misclassification pada kategori error type II sebesar 16.7\%. Ketepatan prediksi kelompok keputusan 0 (termasuk kedalam Bank Umum Syariah yang sehat) sebanyak 42 responden (100\%) dan tidak ada yang berpindah ke kelompok 1 (Kelompok yang mengalami financial distress). Sementara itu 2 responden $(16.1 \%)$ berada di kelompok keputusan 1 (berada dalam kondisi financial distress) dari dugaan awal sebanyak 12 observasi responden dan terdapat 2 responden (16.7\%) pindah ke kelompok 0 (Bank Umum Syariah yang sehat) yaitu Bank Muamalat dengan observasi tahun 2012 dan Bank Jabar Syariah Banten dengan observasi tahun 2014. Sehingga dapat dihitung ketepatan fungsi diskriminan adalah sebesar $(42+2) / 54$ atau sebesar $81.48 \%$.

\section{Tabel 5. Hasil Klasifikasi}

\begin{tabular}{|l|c|c|c|}
\hline \multirow{2}{*}{\multicolumn{1}{|c|}{ Y }} & \multicolumn{2}{|c|}{ Group Membership Yang Diprediksi } & \multirow{2}{*}{ Total } \\
\cline { 2 - 3 } & Sehat & Finacial Distress & \\
\hline Sehat (Count) & 42 & 0 & 42 \\
Financial Distress (Count) & 2 & 10 & 12 \\
Sehat (\%) & 100 & 0 & 0 \\
Financial Distress (\%) & 16.07 & 83.03 .00 & 100 \\
\hline
\end{tabular}

Sumber: SPSS, diolah kembali.

Tabel 5 menunjukan jumlah kasus (observasi) sebanyak 54 yang di proses dan tidak terdapat data yang hilang (missing) sehingga data yang digunakan pada output berjumlah 54 observasi, kelompok dengan keputusan 0 (sehat) sebanyak 42 observasi sedangkan kelompok dengan keputusan sebanyak 1 (mengalami financial distress) sebanyak 12 observasi.

\section{Variabel Dominan dalam Memprediksi Financial Distress pada Bank Umum Syariah di Indonesia}

Hasil analisis menunjukkan bahwa diantara variabel-variabel penduga berupa rasio keuangan RoA, BOPO, Current Asset terhadap Current Liabilities, NPF, Equity terhadap Liabilities dan FDR ternyata didapatkan hanya variabel NPF yang signifikan dapat memprediksi kondisi financial distress pada Bank Umum Syariah di Indonesia. Dengan demikian variabel NPF dapat dikatakan variabel yang dominan dalam meprediksi kondisi financial distress pada Bank Umum Syariah dengan nilai signifikansi sebesar 0.002 yang dihasilkan oleh analisis regresi logistik, dan nilai signifikansi 0.000 yang dihasilkan oleh MDA dengan kedua nilai tersebut lebih kecil dari taraf nyata $5 \%$. 
Estimasi model prediksi kondisi financial distress yang dihasilkan oleh MDA mengindikasikan kenaikan NPF sebsesar 1\% akan menghasilkan kecenderungan suatu bank umum syariah berpeluang mengalami kondisi financial distress sebanyak 0.34 kali.

\section{Keakuratan Prediksi dan Daya Klasifikasi Model MDA}

Analisis MDA mampu menghasilkan ketepatan prediksi suatu bank umum syariah termasuk kedalam Bank Umum Syariah yang sehat sebanyak 42 observasi (100\%) dan tidak ada yang berpindah ke Kelompok yang mengalami financial distress. Sementara itu 2 observasi (16.7\%) berada di kondisi financial distress dari dugaan awal sebanyak 12 Bank Umum Syariah dan terdapat 2 observasi (16.7\%) terkoreksi menjadi kelompok Bank Umum Syariah yang sehat. Ketepatan fungsi diskriminan adalah $81.48 \%$.

Kemampuan variabel diskriminan NPF untuk menjelaskan variasi antar kelompok Bank Umum Syariah yang sehat dan yang mengalami financial distress adalah $45.1584 \%$. Hal ini sejalan dengan penelitian Ben Chin, etc (2010) yang mengatakan bahwa walaupun berbagai macam alat statistic yang popular digunakan baru-baru ini, namun MDA masih merupakan alat analisis yang reliabel. Yakymova dan Kuz (2019) mengatakan bahwa model MDA dapat digunakan untuk memprediksi financial Distress perusahaan di Ukraina denga prediktor terdiri dari equity-assets ratio, the current ratio, dan the average accounts receivable turnover. Sementara Bunyaminu, Alhasan dan Mohammed Issah (2012), Al-Shaleh dan Al-kandari (2012), Kahlili Araghi dan Maryam (2013) serta Jaffari dan Zeesan (2017) mengatakan bahwa daya klasifikasi dan keakuratan tertinggi dihasilkan oleh model lain (model logistik). Al-Shaleh dan Alkandari (2012) mengatakan bahwa regresi logistik dapat digunakan sebagai suatu early warning system terhadap financial distress suatu bank umum dengan rasio investment in securities to total assets, loans to total assets, dan loans to deposits merupakan prediktor yang signifikan dalam memprediksi kondisi financial distress Bank Umum di Kwuait. Sementara Samanhiya, et al (2016) mengatakan bahwa poor corporate governance dan board size yang lebih kecil berkontribusi terhadap kondisi financial distress pada Bank Umum di Ghana. Mihalovič, M (2016) mengatkan bahwa prediktor yang paling signifikan dalam memprediksi financial distress Reepublik Slovakia terdiri dari net income to tatal assets, current ratio and current liabilities to total assets.

\section{PENUTUP}

Prediksi Kondisi Financial Distress Bank Umum Syariah di Indonesia telah dilakukan dengan menggunakan Multiple Discriminant Analysis. Hasil analisis MDA menunjukkan variabel yang dominan dapat memprediksi suatu Bank Umum Syariah mengalami kondisi Financial Distress adalah variabel NPF.

Hasil penelitian ini dapat dijadikan usulan untuk penggunaan model yang akurat dalam memprediksi kondisi financial distress pada Bank Umum Syariah dan menjadikan variabel pada model sebagai early warning system untuk memitigasi terjadinya risiko pembiayaan bermasalah yang cenderung dapat mengakibatkan suatu bank umum syariah berada pada kondisi financial distress. 
Pembiayaan bermasalah (NPF) yang semakin besar atau semakin tinggi membuat kualitas pembiayaan pada bank menjadi semakin buruk karena adanya penambahan pencadangan pada pembiayaan bermasalah yaitu dari pembiayaan yang kurang lancar, diragukan serta macet. Pembentukan cadangan berupa Cadangan Kerugian Penurunan Nilai (CKPN) sebesar 15\% (kategori Kurang Lancar), 50\% (kategori Diragukan) dan 100\% (kategori Macet) dari pembiayaan yang disalurkan. NPF yang semakin tinggi membuat risiko kredit pada bank semakin besar, dan pada kondisi tersebut bank memiliki hambatan untuk memutarkan dananya khususnya pada penyaluran pembiayaan. NPF yang tinggi menyebabkan perputaran aliran dana bank menjadi terhambat. Jika NPF tinggi, maka pembiayaan bermasalah tinggi dan menyebabkan potensi bank mendapatkan pengembalian dana tersebut menjadi terhambat, sehingga pada akhirnya menghambat perputaran dana pada bank. Pada sisi lain, NPF yang tinggi menyebabkan bank kehilangan sumber pendapatan yang berasal dari pendapatan bagi hasil ataupun pendapatan margin keuntungan, sehingga menghasilkan penurunan laba bank. Hal ini berpotensi meningkatkan peluang suatu bank berada pada kondisi financial distress.

Oleh karena itu, jika perbankan tidak dapat menganalisis risiko-risiko yang ada terutama risiko kredit, maka hal tersebut bisa saja mempengaruhi kondisi kesehatan bank itu sendiri dan akan mangalami financial distress yang berujung pada kebangkrutan.

Penelitian lanjutan dapat dilakukan dengan menggunakan proksi kriteria financial distress lainnya, menggunakan pendekatan model lainnya serta menambahkan variabel lain dalam membangun model prediksi financial distress pada Bank Umum Syariah di Indonesia.

\section{DAFTAR PUSTAKA}

Al-Saleh, Mohammad Ahmad \& Ahmad Mohammad Al-Kandari. 2012. World Review of Business Research. Vol 2. No 6. November 2012. Pp 26-45 : Prediction of Financial Distress for Commercial Banks in Kuwait.

Altman, Edward I. 1968. " Financial Ratios, Discriminant Analysis and the Prediction of Corporate Bankrupty." The Journal of Finance (September) :589-609.

Altman, I. Edward. 1993. Corporate Financial Distress and Bankruptcy: A Complete Guide to Predicting and Avoiding Distress and Profiting from Bankruptcy, Second Edition, John Willey Sons, Inc. New York.

Anggraeni, Retno Dewi dkk. 2014. "Penerapan Model Multiple Discriminant Analysis Untuk Memprediksi Financial Distress (Studi pada Sektor Industri Barang Konsumsi yang Listing di Bursa Efek Indonesia Periode 2009-2012)".

Araghi, Kalili; Maryam. 2013. Journal of Finance \& Accounting Vol. 5 No. 1 p. 48-59. : Comparing Logit, Probit and Multiple Discriminant Analysis Models in Predicting Bankruptcy of Companies.

Ben Chin-Fook Yap, etc. 2010. International Research Journal of Finance and Economics p. 166-176 : How Well Do Finacial Ratios and Multiple Dpiscriminant Analysis Predict Company Failures in Malaysia. 
Bunyaminu, Alhasan; Mohammed Issah. 2012. International Research Journal of Finance and Economics Issue 94 p. 6-22 : "Predicting Corporate Failure of UK's Listed Companies : Comparing Multiple Discriminant Analysisi and Logistic Regression". Brigham, Eugene F. dan Joel. F. Huston. 2001. "Manajemen Keuangan”. Jakarta: Erlangga.

Ehab Zaki, Rahim Bah, Ananth Rao. 2011. International Journal of Managerial Finance, Vol. 7 Issue: 3, pp.304-320 : Assessing probabilities of financial distress of banks in UAE.

Fauzi, Ahmad., 2001. Pokok-Pokok Basel Core Principle, BEI News Edisi 5 Tahun II (Maret-April 2001).

Fahmi, Irham. 2011. Analisis Laporan Keuangan. Bandung: Alfabeta.

Gamayuni, R. R. 2011. Analisis Ketepatan Model Altman Sebagai Alat Untuk Memprediksi Kebangkrutan. Jurnal Akuntansi dan Keuangan, vol. 16 No.2.

Garson, David G., 2006. Logistic Regression .www.chass.ncsu.edu/Garson/Pa765/Logistic.htm.

Gitman, Lawrence J. 2000. Principles of Managerial Finance. Massachusetts: Addison Wesley Publishing Company.

Gudjarati, Damodar. 2003. Basic Econometrics Fourth Edition, Mc Graw Hill, New York., 2003.

Hair JR, Joseph. 1992. Multivariate Data Analysis. Macmillian Publishing Company. New York.

Hosmer, David W dan Stanley Lemeshow. 1989. Applied Logistic Regression, John Willey Sons, Inc., New York.

Husna, Nurul \& R. Abdul Rahman. 2012. International Journal of Trade, Economics \& Finance : Vol. 3 No. 3, June 2012 : Financial Distress Detection Model for Islamic Banks.

Ihsan, Dwi Nur'aini dan Sharfina Putri Kartika. 2015. Jurnal Ekonomi Vol 14 (2), Oktober 2015, P-ISSN : 1412-8969, E-ISSN : 2461-0771 Hal 113-146 : Potensi Kebangkrutan Pada Sektor Perbankan Syariah untuk Menghadapi Perubahan Lingkungan Bisnis.

Jaffari, Asad Ali dan Zeeshan Ghafoor. 2017. Reasearch Journal of Finance and Accounting ISSN 2222-1697 (Paper) ISSN 2222-2847 (Online) Vol 8 N0. 3 p. 81-100 : "Predicting Corporate Bankruptcy in Pakistan A Comparative Study of Multiple Discriminant Analysis (MDA) and Logistic Regression".

Jana Ilieva, Natasha Ristovska, and Saso Kozuharov and Jana Ilieva. 2017. Banking without Interest. UTMS Journal of Economics 8 (2): 131-139.

Jean-Yves Moisseron, Bruno-Laurent Moschetto, Frédéric Teulon. 2015. International Business \& Economics Research Journal - September/October 2015 Volume 14, Number 5: "Islamic Finance: A Review Of The Literature".

Mabid Ali Al-Jarhi. 2017. "An economic theory of Islamic finance", ISRA International Journal of Islamic Finance, Vol. 9 Issue: 2, pp.117-132, https://doi.org/10.1108/IJIF-07-2017-0007. 
Mihalovič, M. 2016. Economics and Sociology, Vol. 9, No 4, pp. 101-118. DOI: 10.14254/2071-789X.2016/9-4/6 : "Performance Comparison of Multiple Discriminant Analysis and Logit Models in Bankruptcy Prediction".

Mishkin, Frederich S., 2001. The Economics of Money, Banking ang Financial Markets, Addison Wesley.

Naseem Al Rahahleh, M. Ishaq Bhatti and Faridah Najuna Misman . 2019. Journal Risk Financial Management12(1), 37; https://doi.org/10.3390/jrfm12010037 : "Developments in Risk Management in Islamic Finance: A Review".

nn.Principles of Efective Banking Supervision, Basel Committee for Banking Supervision,.

nn., 2000. Manajemen Investasi dan Portfolio: 1-14, Penerapan Z-Score untuk Memprediksi Kesulitan Keuangan dan Kebangkrutan Perbankan Indonesia, Studi Kasus Kebijaksanaan Bank Indonesia Tanggal 13 Maret 1999 Terhadap 18 Bank Publik. http://www.geocities.com/rahmatov/Z-Score.PDF.

Pindyck, Robert S dan Daniel L. Rubinfeld., 1998. Econometric Models and Economic Forecasts Fourth Edition, Mc Graw Hill, New York.

Prusak, Blazes. 2018. International Journal of Financial Studies p.1-28: "Review of Research into Enterprise Bankruptcy Prediction in Selected Central and Eastern European Countries".

Rahman, Sahidur et all., 2004, Asian Economic Journal Vol. 18 No. 1 : Identifying Financial Distress Indicators of Selected Banks in Asia.

Santoso, Singgih. 2003. "SPSS Statistik Multivariat". Jakarta: PT Elex Media Komputindo Gramedia.

Samanhyia, S., Mintah Oware, K. and Anisom-Yaansah, F., 2016. Financial Distress and Bankruptcy Prediction: Evidence from Ghana. Expert Journal of Finance, 4, pp. 52-65.

Tzong-Huei Lin. 2009. Mathematics, Neurocomputing 72 (2009) 3507-3516. DOI:10.1016/j.neucom.2009.02.018. "A cross model study of corporate financial distress prediction in Taiwan: Multiple discriminant analysis, logit, probit and neural networks models".

Yakymova, Larysa dan Vasyl Kuz. 2019. "The Use of Discriminant Analysis in The Assessment of Municipal Company's Financial Health" : Economic and Sosiology, 12 (2), 64-78, doi : 10.14254/2071-789X.2019/12-2/4 